\title{
The viability of biomethane as a future transport fuel for Zambian towns: A case study of Lusaka
}

\author{
Agabu Shane ${ }^{1^{*}}$, Young Kafwembe ${ }^{2}$, Pride Kafwembe ${ }^{3}$ \\ 1 Mining Engineering Department, School of Mines and Mineral Sciences, Copperbelt University, Jambo Drive, \\ Riverside, P.O. Box 21692, Kitwe, Zambia. \\ 2 Accounting and Finance Department, School of Business, Copperbelt University, Jambo Drive, Riverside, P.O. \\ Box 21692, Kitwe, Zambia. \\ 3 Peri Urban Department, Lusaka Water and Sewerage Company Limited, Katemo Road, P.O. Box 50198, Lu- \\ saka, Zambia.
}

\begin{abstract}
The objective of the study was to determine the viability of biomethane as a transport fuel for Zambian urban towns. The study revealed good potential for biomethane production and use as a transport fuel in Zambian towns, using Lusaka as a case example. There is 3.67 million $\mathrm{m}^{3}$ biomethane potential from municipal solid waste alone in Lusaka. About 3000 tonnes of organic fertiliser would replace an equivalent amount of chemical fertiliser. The replaced chemical fertiliser would lead to about 5.816 $\mathrm{GgCO}_{2}$ eqy $^{-1}$ as avoided emissions. The study showed a positive net present value at the prevailing market interest rates of $28-40 \%$; the project would become unviable at interest rates higher than that. It was estimated that the project would recover its initial investment in a maximum of two years. The research findings have closed data and information gaps in Zambia and have potential to contribute to academic research, policymaking, investments, financing and interested parties.
\end{abstract}

Keywords: biogas, municipal solid waste, environmental, social and economic benefits

Journal of Energy in Southern Africa 29(3): 86-95

DOI: http://dx.doi.org/10.17159/2413-3051/2017/v29i3a4893

Published by the Energy Research Centre, University of Cape Town ISSN: 2413-3051

http://journals.assaf.org.za/jesa

Sponsored by the Department of Science and Technology

* Corresponding author: Tel: +26 (0) 977 457561;

email: agabu.shane@cbu.ac.zm 


\section{Introduction}

Biogas is the main product of the anaerobic digestion (AD) of organic waste and wet biomass. The organic fraction of municipal solid waste (MSW)' slaughterhouse waste, agricultural and forest residues, livestock manure, dedicated energy crops, and sewage waste are all potential feedstock types that can be used to produce biogas [1,2]. During the AD process, a major portion of the carbon compounds are converted to methane $\left(\mathrm{CH}_{4}\right)$, carbon dioxide $\left(\mathrm{CO}_{2}\right)$ and water $[3,4]$. Biogas normally contains $50-70 \% \mathrm{CH}_{4}, 35-50 \% \mathrm{CO}_{2}$ [5] and trace gases like hydrogen sulphide $\left(\mathrm{H}_{2} \mathrm{~S}\right)$, depending on the feedstock type [6].

The co-product of anaerobic digestion is organic fertiliser, which is preferable to chemical fertiliser in terms of environmental impacts [7] and can lead to higher yields [8]. Traditionally, biogas has been used by households as a source of energy for cooking [9] and combined heat power plants to produce electric power and heat [10]. Countries like Germany, Sweden, Switzerland, Italy, Hong Kong and Ireland demonstrated that biogas could be upgraded to biomethane and used more efficiently by injecting it into the compressed natural gas grid or used as a transport fuel for both heavy and light duty vehicles $[11,12]$.

The main objective of this study was to assess the viability of biomethane production and use as a transportation fuel. The study first assessed the biogas potential from municipal solid waste in Lusaka, discussed the upgrading processes of biogas in general, and estimated how much biomethane could be available for light-duty vehicles weighing 0.75-3.00 tonnes. The focus was on these vehicles because they have small engines and mostly use petrol, which can easily be switched to biomethane [13]. The study then looked at the potential environmental, health and sanitation, and social and economic benefits of adopting biomethane as a future transport fuel in Zambia.

\section{Methodology}

The information and data used in this study was obtained from the Central Statistics Office reports, official reports from government ministries, non-governmental and community-based organisations, the Food and Agriculture Organisation statistics database, and publications on similar studies in other countries where such projects have been and are being implemented.

\subsection{Biogas potential}

Biogas potential was determined according to Sanches-Pereira et al. [14]) and Shane et al. [15]. Jingura and Matengaifa [16] stated the biogas potential as the product of quantity of feedstock and the biogas potential per ton of feedstock less $6 \%$ losses. The biogas potential can be estimated according to Equation 1. The population from different wards of Lusaka province was obtained from the Census of Population and Housing report [17]. The generated solid waste per capita used in the estimation was obtained from the Zambia Environmental Outlook report for which the Environmental Council of Zambia, now the Environmental Management Agency (ZEMA), carried out studies and determined this figure. The MSW collection efficiency was also obtained from studies by ZEMA and Senkwe et al. [18]. The organic matter content and the biogas potential were taken from similar studies done in subSaharan African countries like Zimbabwe and Uganda. A 6\% biogas loss was also incorporated into the formula [19] to account for characteristic leakages in production of the biogas.

$$
B P_{M S W}=\sum N_{i} \times Q_{p c} \times C_{e f f} \times O M_{f} \times B_{p}
$$

where $B P_{M S W}$ is the biogas potential from municipal solid waste $\left(\mathrm{m}^{3} \mathrm{~d}^{-1}\right) ; N_{i}$ is the $i$ th ward total human population; $Q_{p c}$ is the quantity of municipal solid waste generated per capita $\left(\mathrm{kgp}^{-1} \mathrm{~d}^{-1}\right) ; C_{\text {eff }}$ is the municipal solid waste collection efficiency or rate of municipal solid waste collection (\%); $O M_{f}$ is the organic matter fraction in the municipal solid waste (\%); and $B_{p}$ is the biogas potential of the organic fraction of the municipal solid waste $\left(\mathrm{m}^{3} \mathrm{~kg}^{-1}\right)$.

\subsection{Organic fertiliser production potential}

The organic fertiliser was estimated using the estimated biogas and/or biomethane potential, the standard ratio of methane in the biogas, standard density of methane and the organic fertiliser that could be produced per unit volume of biogas generated. These parameters were obtained from similar studies on organic fertiliser production, according to Equation 2 [20-22].

$$
Q_{f}=\frac{M_{\mathrm{CH}_{4}}}{\rho_{\mathrm{CH}_{4}} \times R_{\mathrm{CH}_{4}} \times V_{B} \times D_{P}}
$$

where $Q_{f}$ is the production rate of fertiliser $\left(\mathrm{kgd}^{-1}\right)$; $M_{\mathrm{CH}_{4}}$ is the mass of methane generated within a year $\left(\mathrm{kgy}^{-1}\right) ; \rho_{\mathrm{CH}_{4}}$ is the density of methane $\left(\mathrm{kgm}^{-3}\right)$; $R_{\mathrm{CH}_{4}}$ is the ratio of methane in the biogas; $\mathrm{V}_{\mathrm{B}}$ is the biogas generated from a unit mass of organic fertiliser $\left(\mathrm{m}^{3} \mathrm{~kg}^{-1}\right.$ of fertiliser); and $D_{\mathrm{p}}$ is the number of days per year of production.

\subsection{Avoided greenhouse gas emissions}

Avoided greenhouse gas (GHG) emissions that were considered were $\mathrm{CO}_{2}$ from chemical fertiliser production, nitrous oxide $\left(\mathrm{N}_{2} \mathrm{O}\right)$ emissions from chemical fertiliser (replaced urea and D-compound) appli- 
cations to managed soils, and non- $\mathrm{CO}_{2} \mathrm{GHG}$ emissions such as combustion of MSW in disposal sites and emissions from fuel combustion. Managed soils are soils that undergo enhancement in terms of their performance and fertility through practices such as tiling, ploughing, and the addition of agricultural lime and fertiliser.

\subsubsection{Avoided greenhouse gas emissions from fertiliser production}

To estimate the amount of GHG emissions from fertiliser production, the amount of GHG emission per $\mathrm{kg}$ of nitrogen fertiliser produced is multiplied by the percentage of nitrogen in the fertiliser and the quantity of fertiliser produced $\left(\mathrm{kgy}^{-1}\right)$, according to Equation 3 [23, 24]. The amount of fertiliser was obtained from the quantified organic fertiliser, which could be replaced by the chemical fertiliser. The nitrogen content was obtained from a standard nitrogen phosphorus and potassium fertiliser used in Zambia, and emission factors are standard factors obtained in chemical fertiliser production.

$$
G H G_{F P}=365 \sum_{i=1}^{n} Q_{f} \times P_{N, i} \times E F_{i} \times 10^{-6}
$$

where $G H G_{F P}=$ GHG emissions from fertiliser production $\left(\mathrm{GgCO}_{2}\right.$ eqy $\left.^{-1}\right) ; Q_{f}=$ quantitate of fertiliser type $i\left(\mathrm{kgd}^{-1}\right)$; percentage of nitrogen in fertiliser type $i(\%)$; and $E F_{i}$ is the $G H G$ emissions per kilogram of fertiliser type $i\left(\mathrm{kgCO}_{2} \mathrm{eqkg}^{-1} \mathrm{~N}\right.$-fertiliser). The values of $\mathrm{GHG}$ emissions per $\mathrm{kg}$ of nitrogen fertiliser produced are given in Table 1. The fertiliser in row one was used in the calculation because of the large number of citations in the literature, which could indicate wide applications in research.

Table 1: Greenhouse gas emissions from fertiliser production.

\begin{tabular}{|c|c|c|c|c|}
\hline Fertiliser type & $N$ & $P$ & $K$ & Source \\
\hline \multirow[t]{3}{*}{$\begin{array}{l}\text { GHG emissions } \\
{\text { (kg CO } \text { Ceqkg }^{-1}}_{\text {fertiliser }}\end{array}$} & 3.30 & 1.10 & 0.73 & $\begin{array}{l}\text { IFA, 2009; } \\
\text { TGO, 2015; } \\
\text { Lal, 2004b }\end{array}$ \\
\hline & 3.30 & 1.57 & 0.50 & (TGO, 2015 \\
\hline & 3.63 & 1.55 & 0.97 & $\begin{array}{l}\text { Kool et al, } \\
2012\end{array}$ \\
\hline
\end{tabular}

\subsubsection{Avoided greenhouse gas emissions from}

fertiliser application to managed soils

The GHG emissions from both chemical and organic fertiliser application to managed soils were estimated according to the Intergovernmental Panel on Climate Change (IPCC) Guidelines for National Greenhouse Gas Inventories, Volume 4 and Chapter 11 [25], Elsgaard [26] and Figueiredo et al. [28].
Equations 4 and 5 were used to calculate direct and indirect nitrous oxide $\left(\mathrm{N}_{2} \mathrm{O}\right)$ emissions, respectively, from the nitrogen, phosphorus and potassium (Dcompound), urea and organic fertiliser application to managed soils. The quantity of chemical fertiliser used in the estimation was based on the equivalent fertiliser that would be replaced by organic fertilisers.

$$
\begin{aligned}
& N_{2} O_{D E}=N \times \frac{44}{28} \times E F_{1} \times 10^{-6} \\
& N_{2} O_{I E}=N\left[\left(F_{\text {Vola }} \times E F_{4}\right)+\left(F_{\text {leach }} \times F_{5}\right)\right] \\
& \times \frac{44}{28} \times 10^{-6}
\end{aligned}
$$

where $\mathrm{N}_{2} \mathrm{O}_{D E}=$ direct $\mathrm{N}_{2} \mathrm{O}$ emissions from synthetic nitrogen additions to the managed soils $\left(\mathrm{Gg} \mathrm{N}_{2} \mathrm{O} \mathrm{yr}^{-1}\right)$; $N=$ consumption in nutrients of $\mathrm{N}$-fertilisers $(\mathrm{kg} \mathrm{N}$ input $\left.\mathrm{yr}^{-1}\right) ; E F_{1}=$ emission factor for $\mathrm{N}_{2} \mathrm{O}$ emissions from $\mathrm{N}$ inputs ( $\mathrm{kg} \mathrm{N} \mathrm{N}_{2} \mathrm{O}-\mathrm{N} / \mathrm{kg} \mathrm{N}$ input); $\mathrm{N}_{2} \mathrm{O}_{I E}=$ indirect $\mathrm{N}_{2} \mathrm{O}$ emissions produced from atmospheric deposition of $\mathrm{N}$, volatilised from managed soils $(\mathrm{Gg}$ $\mathrm{N}_{2} \mathrm{O}-\mathrm{N}$ yr $\left.^{-1}\right) ; F_{\text {vola }}=$ fraction of applied synthetic Nfertiliser materials that volatilises as $\mathrm{NH}_{3}$ and $\mathrm{NO}_{x}$ ( $\mathrm{kg} \mathrm{N}$ volatilized/ $\mathrm{kg}$ of $\mathrm{N}$ applied); EF4 = emission factor for $\mathrm{N}_{2} \mathrm{O}$ emissions from atmospheric deposition of $\mathrm{N}$ on soils and water surfaces, $\mathrm{kg} \mathrm{N}-\mathrm{N}_{2} \mathrm{O} / \mathrm{kg}$ $\mathrm{NH}_{3}-\mathrm{N}+\mathrm{NO}_{\mathrm{x}}-\mathrm{N}$ volatilised; $F_{\text {leach }}=$ fraction of applied synthetic $\mathrm{N}$-fertiliser material that leaches as $\mathrm{NH}_{3}$ and $\mathrm{NO}_{\mathrm{x}}$ ( $\mathrm{kg} \mathrm{N}$ leached/kg of $\mathrm{N}$ additions); and $E F_{5}=$ emission factor for $\mathrm{N}_{2} \mathrm{O}$ emissions from $\mathrm{N}$ leaching and runoff ( $\left.\mathrm{kg} \mathrm{N} \mathrm{N}_{2} \mathrm{O}-\mathrm{N} / \mathrm{kg} \mathrm{N}\right)$.

\subsubsection{Avoided greenhouse gas emissions from} burning of municipal solid waste in dump sites The methane and nitrogen oxide emissions were estimated according to the IPCC, volume 2 on energy, chapter 2: stationary combustion, under tier one as stated in Equation 6. The open air burning of the MSW considered under stationary combustion because of the immobile burning. The MSW was left to burn where it was dumped. The combusted fuel was obtained from the amount of MSW that ended up in disposal sites and the emissions factors were default emissions factors as stated in IPCC 2006 [28]. Carbon dioxide emissions accounted for the majority of the GHG emissions from open burning of MSW. However, since its source is biogenic, it was ignored in the calculations.

$E_{G H G, F}=F C F \times E F_{G H G, F}$

where $E_{G H G, F}=$ emissions of a given GHG by type of fuel $F(\mathrm{~kg} \mathrm{GHG}) ; F C_{F}=$ amount of fuel combusted (TJ); and $E F_{G H G, F}=$ default emission factor of a given GHG by type of fuel (kg gas/TJ). 


\subsubsection{Avoided emissions from fossil fuel consumption}

The GHG emissions from fossil fuel were estimated using the average combusted fuel for each fuel types. The historical statistics on fuel consumption in Lusaka were obtained from the energy statistics report by the Central Statistics Office. Equation (7) was adopted from the IPCC [17] to estimate these GHG emissions.

$E_{G H G}=\sum_{i=1}^{n}\left[F_{i} \times E F_{i}\right]$

where $E_{G H G}=$ GHG emissions $(\mathrm{kg}) ; F_{i}=$ fuel type $\mathrm{i}$ sold (TJ); and $E F_{i}=$ emission factor for fuel type i $\left(\mathrm{kgTJ}^{-1}\right)$.

The magnitude of avoided GHG emissions from the use of biomethane in Lusaka equals the GHG emissions from petrol consumption minus the GHG emissions from an equivalent energy from biomethane that would be produced from municipal solid waste.

\subsection{Economic viability}

The net present value (NPV) and the payback period (PBP) $[29,30]$ are the two methods that were used to estimate the economic viability of the biomethane use as a future transport fuel in Lusaka. The basis for using NPV was that if the project NPV is greater than zero the project is considered to be profitable over that time period and the opposite applies for NPV less than zero [31]. The PBP considers the length of time in which the investment is recovered. Equations 8-11 were used to estimate the NPVs and the PBP.

$$
\begin{aligned}
& N P V_{n}=\left(P V_{1}+P V_{2}+\ldots . .+P V_{n}\right)-I I C \\
& P V_{n}=F V_{n} * P V F_{n, i} \\
& P V F_{n, i}=\frac{1}{(1+i)^{n}} \\
& P B P=\frac{I I C}{C I}
\end{aligned}
$$

where $N P V_{n}=\mathrm{NPV}$ of a project over $n$ years; $P V_{1} \ldots P V_{n}=$ project cash flows from each project year one to $n$; IIC = initial investment cost; $F V_{n}=$ the known future value of the project cash flow in year $n ; P V F_{n i}=$ a present value factor for the year $(n)$ and the project discount rate (i); $P B P$ is the payback period in years and $C I$ is the cash inflow.

\section{Results and discussion}

3.1 Biogas potential from municipal solid waste for Lusaka

The waste generation per capita of $0.5 \mathrm{kgd}^{-1}$, MSW collection efficiency of $40 \%$ and organic matter fraction of $40 \%[32,33]$ were used in the estimation. Biogas potential of $128 \mathrm{~m}^{3} \mathrm{t}^{-1}$ with $6 \%$ losses was used [16] for MSW. The total estimated biogas potential was $16777 \mathrm{~m}^{3} \mathrm{~d}^{-1}$, bringing the total to 6123 $605 \mathrm{~m}^{3} \mathrm{y}^{-1}$. Taking the biogas to constitute $60 \% \mathrm{me}$ thane [21], there would be about 3.67 million $\mathrm{m}^{3} \mathrm{y}^{-1}$ of biomethane potential in Lusaka. Table 2 presents the estimated biogas potential.

\subsection{Organic fertiliser production}

Using Equation 2, the co-product of biogas (bioslurry) that would be produced was estimated to be just above 3 kilotons per annum. With proper packaging and branding, the organic fertiliser could result in an income to the developer and offset some crucial costs. The price of chemical fertiliser was used as a proxy for the estimation of earning from organic fertiliser sales. A $50 \mathrm{~kg}$ bag of chemical fertiliser (NPK and/or urea) costs between USD 38.00 and USD 46.00 [34], yielding $0.76-0.92 \mathrm{USD} / \mathrm{kg}$ of Dcompound or urea. The net income from organic fertiliser sales would be equal to the product between the quantity of the organic fertiliser produced and the unit cost less processing, storage, marketing and miscellaneous costs, which were estimated at $50 \%$ based on similar studies [35]. The net earnings from organic fertiliser sales would range from USD 1.2-1.4 million/year.

\subsection{Avoided greenhouse gas emissions from chemical fertiliser production}

Using Equation 3, the GHG emissions resulting from chemical fertiliser production were estimated to be approximately $2.836 \mathrm{GgCO}_{2}$ eqy $^{-1}$. The emission factor $\left(\mathrm{EF}_{\mathrm{i}}\right)$ was taken as be equal to $3.30 \mathrm{~kg} \mathrm{CO}$ eq $\mathrm{kg}^{-1}$ for $\mathrm{N}$-fertilisers $[23,36]$. The use of organic fertiliser would, consequently, not produce chemical fertilisers of an equivalent amount. Table 3 gives the calculated GHG emissions avoided from the production of urea and D-compound fertilisers.

\subsection{Avoided greenhouse gas emissions from chemical fertiliser application to managed soils}

Taking D-compound, urea and organic fertiliser to contain 10, 46 and $10 \%$ nitrogen respectively, a net $2.980 \mathrm{GgCO}_{2}$ eq y $\mathrm{y}^{-1}$ was estimated (Table 4). Urea contributed the largest percentage to the net GHG emissions from chemical fertiliser application to managed soils because it has the highest nitrogen percentage [37-39]. 
Table 1: Daily biogas potential for Lusaka.

\begin{tabular}{lrcc}
\hline \multicolumn{1}{c}{ Constituency } & Population & $\begin{array}{c}\text { Municipal solid waste } \\
\text { generated }\left(\mathrm{kgd}^{-1}\right)\end{array}$ & $\begin{array}{c}\text { Biogas potential } \\
\left(\mathrm{m}^{3} \mathrm{~d}^{-1}\right)\end{array}$ \\
\hline Chawama & 184227 & 14738 & 1773 \\
Kabwata & 171224 & 13698 & 1648 \\
Kanyama & 366170 & 29294 & 3525 \\
Lusaka Central & 125030 & 10002 & 1203 \\
Mandevu & 353807 & 28305 & 3406 \\
Matero & 278693 & 22295 & 2683 \\
Munali & 263828 & 21106 & 2540 \\
\hline Total & 1742979 & 139438 & 16777 \\
\hline
\end{tabular}

Table 3: Greenhouse gas emissions from fertiliser production.

\begin{tabular}{lcc}
\hline Fertiliser production & Quantity & $\mathrm{CO}_{2}$ eq $\left(\mathrm{Ggg}^{-1}\right)$ \\
\hline Urea & 1534388 & 2.329 \\
D-compound & 1534388 & 0.506 \\
\hline Total & & 2.836 \\
\hline
\end{tabular}

Table 4: Greenhouse gas emissions from fertiliser application to managed soils.

\begin{tabular}{lcccc}
\hline & $\begin{array}{c}\text { Quantity } \\
\left(\mathrm{kgy}^{-1}\right)\end{array}$ & $\begin{array}{c}\text { Direct } \mathrm{N}_{2} \mathrm{O} \\
\left(\mathrm{kggy}^{-1}\right)\end{array}$ & $\begin{array}{c}\text { Indirect } \mathrm{N}_{2} \mathrm{O} \\
\left(\mathrm{kggy}^{-1}\right)\end{array}$ & $\begin{array}{c}\mathrm{CO}_{2} e q \\
\left(\mathrm{Ggg}^{-1}\right)\end{array}$ \\
\hline Chemical fertiliser (D-Compound) & 1534388 & 2411 & 259 & 0.83 \\
Chemical fertiliser (Urea) & 1534388 & 11091 & 1192 & 3.81 \\
Organic fertiliser & 3068776 & $(4822)$ & $(518)$ & $(1.66)$ \\
\hline Total & 8680 & 933 & 2.980 \\
\hline Note: Values in parentheses are negative. & & & \\
\hline
\end{tabular}

\subsection{Avoided greenhouse gas emissions from petrol consumption}

Equation 8 was used to compute the GHG emissions from biomethane and equivalent amount of fossil fuel (petrol) that would be replaced by the biomethane. Default emission factors for tier 1 from the IPCC were used in the calculation. When calculating the total energy from each of the two energy sources, 39.82 and $34.20 \mathrm{MJm}^{-3}$ were used as calorific values for biomethane and petrol respectively [40]. The avoided GHG emissions resulting from the use of biomethane as a transport fuel were estimated as the difference between the GHG emissions from the consumption of fossil fuel and the GHG emissions from the biomethane of an equivalent energy. Equation (8) was also used to estimate the amount of GHG emissions from petrol consumption in Lusaka and GHG emissions from an equivalent energy of biomethane that could replace the petrol. The biomethane energy amounted to $146 \mathrm{TJy}^{-1}$. Table 5 shows that the total GHG emissions from this biomethane were estimated to be $0.418 \mathrm{GgCO}_{2}$ eqy $^{-1}$. This biomethane would replace an equivalent of $146 \mathrm{TJy}^{-1}$ of energy from petrol. A total 11.000 $\mathrm{GgCO}_{2}$ eqy $^{-1}$ of $\mathrm{GHG}$ emissions would be recorded from the use of petrol (Table 6). Using biomethane would obviate $10.582 \mathrm{GgCO}_{2}$ eqy ${ }^{-1}$ of GHG emissions. This contribution from the use of biomethane as a transport fuel would be about $5 \%$ of the total GHG emissions from petrol consumption in Lusaka. This means that $95 \%$ GHG emissions from fossil petrol would be avoided if $146 \mathrm{TJy}^{-1}$ biomethane from MSW is produced and used in Lusaka.

\subsection{Avoided greenhouse gas emissions from burning municipal solid waste in dump sites} Waste is normally dumped in legal and illegal sites and later burnt [18, 41-42]. With MSW being used to produce biogas and biomethane, these emissions are reduced to at least half. 
Table 5: Greenhouse gas emissions from biomethane consumption as a transport fuel.

\begin{tabular}{lcccccc}
\hline & Energy & \multicolumn{2}{c}{ Emission factors } & \multicolumn{2}{c}{ Emissions } & $\mathrm{CO}_{2}$-eq \\
\cline { 2 - 7 } & $\left(\mathrm{TJy}^{-1}\right)$ & $\begin{array}{c}\mathrm{CH}_{4} \\
\left(\mathrm{kgTJ}^{-1}\right)\end{array}$ & $\begin{array}{c}\mathrm{N}_{2} \mathrm{O} \\
\left(\mathrm{kgTJ}^{-1}\right)\end{array}$ & $\begin{array}{c}\mathrm{CH}_{4} \\
\left(\mathrm{kgy}^{-1}\right)\end{array}$ & $\begin{array}{c}\mathrm{N}_{2} \mathrm{O} \\
\left(\mathrm{kgg}^{-1}\right)\end{array}$ & $\left(\mathrm{Ggy}^{-1}\right)$ \\
\hline Biomethane & 146 & 92 & 3 & 13432 & 438 & 0.418 \\
\hline $\mathrm{CH}_{4}=$ methane, $\mathrm{N}_{2} \mathrm{O}=$ nitrous oxide, $\mathrm{CO}_{2}=$ carbon dioxide & & \\
\hline
\end{tabular}

Table 6: Greenhouse gas emissions from petrol consumption as a transport fuel.

\begin{tabular}{lcccccccc}
\hline & Energy & \multicolumn{3}{c}{ Emission factors } & & Emissions & & $\mathrm{CO}_{2}$-eq \\
\cline { 2 - 8 } & $\left(\mathrm{TJy}^{-1}\right)$ & $\begin{array}{c}\mathrm{CO}_{2} \\
\left(\mathrm{kgTJ}^{-1}\right)\end{array}$ & $\begin{array}{c}\mathrm{CH}_{4} \\
\left(\mathrm{KgTJ}^{-1}\right)\end{array}$ & $\begin{array}{c}\mathrm{N}_{2} \mathrm{O} \\
\left(\mathrm{KgTJ}^{-1}\right)\end{array}$ & $\begin{array}{c}\mathrm{CO}_{2} \\
\left(\mathrm{kgy}^{-1}\right)\end{array}$ & $\begin{array}{c}\mathrm{CH}_{4} \\
\left(\mathrm{kgy}^{-1}\right)\end{array}$ & $\begin{array}{c}\mathrm{N}_{2} \mathrm{O} \\
\left(\mathrm{kgy}^{-1}\right)\end{array}$ & $\left(\mathrm{Ggy}^{-1}\right)$ \\
\hline Petrol & 146 & 69300 & 25 & 8.0 & 10117800 & 3650 & 1168 & 11 \\
\hline $\mathrm{CH}_{4}=$ methane, $\mathrm{N}_{2} \mathrm{O}=$ nitrous oxide, $\mathrm{CO}_{2}=$ carbon dioxide \\
\hline
\end{tabular}

Table 7: GHG emissions from the burning of municipal solid waste in dump sites.

\begin{tabular}{ccccccc}
\hline $\begin{array}{c}\text { Energy } \\
(\mathrm{TJy}-1)\end{array}$ & $\begin{array}{c}\mathrm{EF} \\
(\mathrm{kg} \mathrm{CH} 4 / \mathrm{TJ})\end{array}$ & $\begin{array}{c}\mathrm{EF} \\
(\mathrm{kg} \mathrm{N2O} / \mathrm{TJ})\end{array}$ & $\begin{array}{c}\mathrm{CH}_{4} \\
(\mathrm{kgy}-1)\end{array}$ & $\begin{array}{c}\mathrm{N}_{2} \mathrm{O} \\
(\mathrm{kgg}-1)\end{array}$ & $\begin{array}{c}\mathrm{CO}_{2} \text {-eq } \\
(\mathrm{Ggy}-1)\end{array}$ \\
\hline $\mathrm{MSW}$ & 146 & 300 & 4 & 43800 & 584 & 1101 \\
\hline \multicolumn{2}{l}{$\mathrm{MSW}=$ municipal solid waste, $\mathrm{EF}=$ emission factor, $\mathrm{CH}_{4}=$ methane, $\mathrm{N}_{2} \mathrm{O}=$ nitrous oxide, $\mathrm{CO}_{2}=$ carbon dioxide } \\
\hline
\end{tabular}

\subsection{Economic benefits}

Initial investment costs consist of installation of anaerobic digesters, a biogas upgrading unit and a biogas storage unit. Other costs included in the initial investment include the cost of conducting an environmental impact assessment for the proposed project and planning, and authorisation costs. Annual recurring costs include operational and maintenance, insurance, depreciation, and tax. Project life was estimated at 25 years [43-44]. The cost of anaerobic digesters, biogas upgrading units and storage, with their installation costs, were obtained from publications of similar studies where this technology is fully developed in Poland, Germany, Italy, China and Kenya [3, 45, 46-48]. According to the Environmental Management Act [49], an Environmental Project Brief costing about USD 1000 (review fee) should be submitted to ZEMA.

The economic viability was determined by estimating the NPV and the simple payback period (PBP) of the proposed project using Equations 9 and 12. Over the years, interest rates in Zambia increased from about $17 \%$ to $28 \%$ and even higher [50-51]. Table 8 presents the important parameters with their sources used in the economic viability determination. The NPV calculations indicated that the proposed project was viable with NPV values ranging from USD 1360000 at $28 \%$ to USD 37000 at $41 \%$ interest rates. At $42 \%$ interest rate, the proposed project became unfeasible as shown in Figure
1. The simple PBP estimations indicated that the proposed project would recover the initial investment cost within two years. The initial investment cost comprised the capital costs, operating expenses and corporate tax. This amounted in year one to USD 6083000 and the annual cash inflow amounted to USD 4467000 . This implied that in year one there would still be USD 1616000 unrecovered. This balance would only be fully recovered in year two. In short, dividing the initial investment cost with the annual cash inflow gives the PBP of 1.4 years, which was therefore taken to be two years.

\section{Enabling platform}

Biomethane can be produced from a broad range of feedstocks suitable for anaerobic digestion, such as livestock manure, municipal solid waste, food processing wastewater, dairy processing, vegetable canning, potato processing, breweries and sugar production. Shane et al. [32] reported that feedstock for bioenergy and biogas is available in abundance in Zambia, with a surplus of 151 million kilograms of crop residues, 6.5 million cubic metres of forest residue, 304 kilotons of MSW and 4.8 kilotons of livestock manure per year. The water and sewerage companies across the country have the potential to provide wastewater as a feedstock for biogas production. Crop and forest residues can also be used for biomethane production if there is proper seeding and with wastewater having microorganisms. 
Table 8: Cash flow for using biomethane as a transport fuel: Lusaka real case example.

\begin{tabular}{|c|c|c|c|c|c|}
\hline Parameter & Unit & Unit cost & Reference & Quantity & USD 1000 \\
\hline Anaerobic digesters & $\mathrm{USDm}^{-3}$ & 109 & [108] & $16777 \mathrm{~m}^{3}$ & 1829 \\
\hline Biogas upgrading unit & $\mathrm{kUSDMW}^{-1}$ & 250 & {$[32,45]$} & $3886 \mathrm{MW}$ & 972 \\
\hline Biogas storage & $\mathrm{kUSDMW}^{-1}$ & 14.39 & {$[44,52]$} & $3886 \mathrm{MW}$ & 56 \\
\hline Environmental impact assessment & USD/unit & 2.60 & [53-54] & 433 units & 1 \\
\hline Planning and authorisation & $\%$ & 5 & ]38] & & 204 \\
\hline Initial capital costs & & & & & 2858 \\
\hline Commercial insurance & $\%$ & 5 & {$[55]$} & & 143 \\
\hline Depreciation & $\%$ & 5.5 & {$[46]$} & & 157 \\
\hline Operational and maintenance & $\mathrm{USD}_{\mathrm{ct}} \mathrm{kwh} \mathrm{h}^{-1}$ & 4 & {$[47]$} & $34038000 \mathrm{kWh}$ & 1362 \\
\hline Total operating expenses & & & & & 1662 \\
\hline \multicolumn{6}{|l|}{ Earnings } \\
\hline From organic fertiliser sales & & & & & 1381 \\
\hline Biomethane sales & $\mathrm{USDCTm}^{3}$ & 84.00 & {$[48]$} & & 3086 \\
\hline Total earnings & & & & & 4467 \\
\hline Corporate tax & $35 \%$ & & {$[56]$} & & 1563 \\
\hline Profit/(loss) & & & & & (1 616) \\
\hline
\end{tabular}

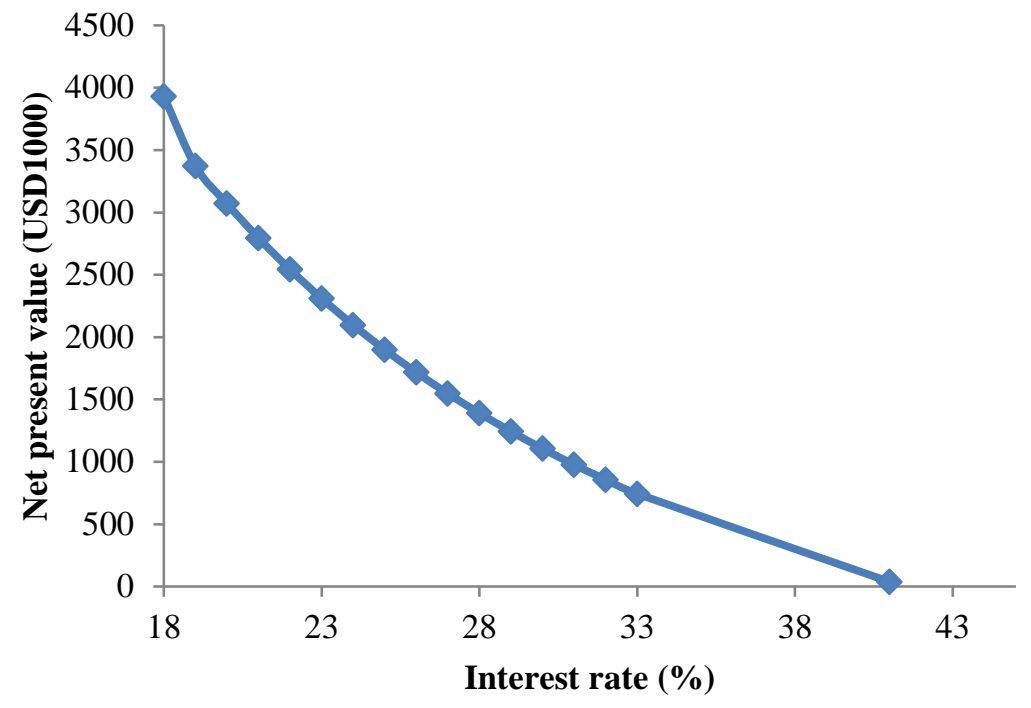

Figure 1: Net present value versus interest rates.

\subsection{Biogas upgrading technology availability}

For biogas to be used in a motor vehicle as a fuel, it requires processing to upgrade it to compressed biomethane gas. Once it has been compressed it can be transported to the end user or its delivery arranged. Upgrading involves removing carbon dioxide, particles, water vapour, hydrogen sulphide, siloxane, and trace gases such as ammonia, chlorine or fluorine compounds, depending on the feedstock from which biogas has been produced [57].

Figure 2 shows the biomethane upgrading technology using wet scrubbing. This technology has been used in Denmark, Sweden, Norway, USA, Italy, Brazil, Hong Kong, Germany and many other European, American and Asian countries. It is a physical process which takes advantage of the fact that carbon dioxide $\left(\mathrm{CO}_{2}\right)$ and hydrogen sulphide $\left(\mathrm{H}_{2} \mathrm{~S}\right)$ are more soluble in water compared to $\mathrm{CH}_{4}$. The pressurised biogas if fed from the bottom and water from the top of the scrubber. The water exits 


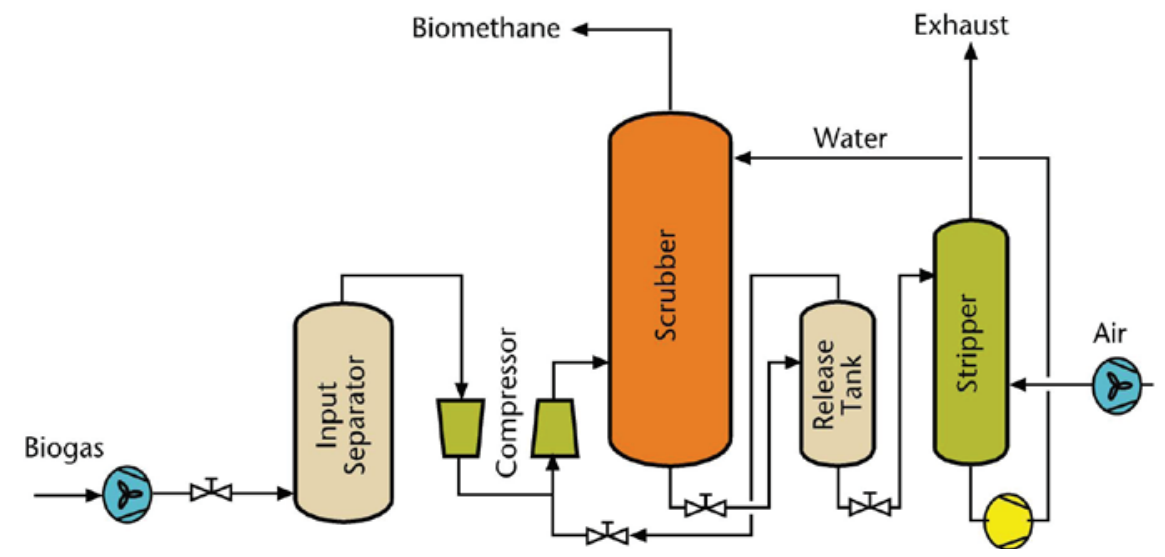

Figure 2: Biomethane upgrading technology - wet scrubbing [58].

with the $\mathrm{CO}_{2}$ and $\mathrm{H}_{2} \mathrm{~S}$ dissolved into it at the bottom while the biomethane exits at the top of scrubber [59].

In Zambia, neither light nor heavy duty motor vehicles are ready to use biomethane with the current engine systems. The fuel system of the motor vehicle must be modified so that it can run on gasoline and biomethane, depending on which one is available. Equipment designed for converting petrol engines to use natural gas or petrol is readily available from a number of manufacturers in many countries in Europe and Asia. Technology is readily available on the market to upgrade biogas to biomethane, which could be compressed and used as a fuel for transport in both heavy and light duty vehicles in Zambia. With appropriate policy and implementation, petrol engine light duty vehicles could be targeted first. This would involve adding a biomethane conversion system to each vehicle in addition to the existing conventional one. The reason for targeting light duty petrol engines is that they have a lower fuel consumption and require less sophisticated engine modification requirements than heavy duty ones. They also commonly use petrol or biomethane, as opposed to heavy duty vehicles which mostly use diesel.

\section{Conclusions}

The study showed a potential to produce 3670000 $\mathrm{m}^{3}$ of biomethane from municipal solid waste with $146 \mathrm{TJy}^{-1}$ of energy. This would result in 10.582 $\mathrm{GgCO}_{2}$ eqy $^{-1}$ of avoided greenhouse gas (GHG) emissions from motor vehicles in Lusaka. The avoided GHG emissions accounted for $95 \%$ of emissions from petrol consumption in Lusaka if biomethane replaces fossil petrol. The biogas production process would produce 3000 tonnes of organic fertiliser as a co-product. The replaced chemical fertiliser would lead to about $5.816 \mathrm{GgCO}_{2} e q y^{-1}$ as non- $\mathrm{CO}_{2} \mathrm{GHG}$ emissions from its production and application. The net present (NPV) of the proposed Lusaka compressed biogas project as a future transport fuel had a positive NPV at the prevailing market interest rates of between $28-41 \%$, but would became unviable if interest rates increased to about $42 \%$. A simple payback period estimation indicated that the project would recover its initial investment in a maximum of two years. The related data and information gaps that existed in Zambia were also identified, with a potential to contribute to research policymaking, investments, financing and allied parties.

\section{Acknowledgement}

Copperbelt University sponsored the presentation of this study in the $8^{\text {th }}$ African Transportation Technology Transfer Conference, 10-13 ${ }^{\text {th }}$ May 2017, Avan Hotel, Livingstone, Zambia.

\section{References}

[1] Singh, A., Smyth, B.M. and Murphy, J.D. 2010. A biofuel strategy for Ireland with an emphasis on production of biomethane and minimization of land-take, Renewable and Sustainable Energy Reviews, 14: 277-88.

[2] Zuccari, F., Santiangeli, A., Dell'Era, A., D'orazio, A., Fiori, C. and Orecchini, F. 2015. Use of biomethane for auto motive application: primary energy balance and well to wheel analysis, Energy Procedia, 81: 255-271.

[3] Boulamanti, A.K., Maglio, S.D., Giuntoli, J. and Agostini, A. 2013. Influence of different practices on biogas sustainability, Biomass Bioenergy, 53:149-61.

[4] Piwowar, A., Dzikuć, M. and Adamczy, K. 2016. Agricultural biogas plants in Poland - selected technological, market and environmental aspects, Renewable and Sustainable Energy Reviews, 58: 69-74.

[5] Coimbra-Araujo, C.H., Mariane, L., Junior, C.B., Frigo, E.P., Frigo, M.S., Araujo, Costa. I.R. and Alves, H.J. 2014. Brazilian case study for biogas 
energy: Production of electric power, heat and automotive energy in condominiums of agroenergy. Renewable and Sustainable Energy Reviews, 40: 826-839.

[6] Ghimire, P.C. 2013. SNV supported domestic biogas programmes in Asia and Africa. Renewable Energy, 49: 90-94.

[7] Nizami, A., Korres, N.E. and Murphy, J.D. 2009. Review of the integrated process for the production of grass biomethane, Environmental Science \& Technology, 43: 8496-508.

[8] Murphy, J., Braun, R., Weiland, P. and Wellinger, A. 2011. Biogas from crop digestion, IEA Bioenergy Task 37. http://www.iea-biogas.net/ [accessed: 15/10/2017].

[9] Mengistu, M.G., Simane, B., Eshete, G. and Workneh, T.S. 2015. A review on biogas technology and its contributions to sustainable rural livelihood in Ethiopia, Renewable and Sustainable Energy Reviews, 48: 306-316.

[10] Budzianowski, W.M. and Budzianowski, D.A. 2015. Economic analysis of biomethane and bioelectricity generation from biogas using different support schemes and plant configurations, Energy, 88: 658-666.

[11] Papacz, W. 2011. Biogas as vehicle fuel, Journal of KONES Powertrain and Transport, 18 (1): 403310.

[12] International Renewable Energy Agency, 2018. Biogas for road vehicles: Technology brief, International Renewable Energy Agency, Abu Dhabi.

[13] Mihic, S. 2004. Biogas fuel for internal combustion engines, annals of the Faculty of Engineering, university of Novi Sad, Serbia and Montenegro.

[14] Sanches-Pereira, P., Lonnqvist, T., Gomez, M.F., Coelho, S.T. and Tudeschini, L.G. 2015. Is natural gas a backup fuel against shortages of biogas or a threat to the Swedish vision of pursuing a vehicle fleet independent of fossil fuels? Renewable Energy, 83: 1187-1199.

[15] Shane, A., Gheewala, S.H. and Kasali, G. 2015. Potential, barriers and prospects of biogas production in Zambia, Journal of Sustainable Energy and Environment, 6: 21-26.

[16] Jingura, R.M. and Matengaifa, R. 2009. Optimization of biogas production by anaerobic digestion for sustainable energy development in Zimbabwe, Renewable and Sustainable Energy Reviews, 13: 1116-20.

[17] Central Statistics Office, Living conditions monitoring survey report 2006 and 2010, Central Statistics Office, 2012, Lusaka.

[18] Senkwe, B.K., Kambole, M.S. and Frijns, J. 1999. Improvement of refuse collection in Kitwe: A participatory approach, SINPA 32, Institute for housing and urban development studies, Rotterdam, Netherlands.

[19] Shane, A., Gheewala, S.H. and Kafwembe, Y. 2017. Urban commercial biogas power plant model for Zambian towns, Renewable Energy, 103: 1-14.
[20] Tonkunya, N. and Wongwuttanasatian, T. 2013. Utilization of biogas diesel mixture as fuel in a fertiliser pelletizing machine for reduction of greenhouse gas emission in small farms, Energy for Sustainable Development, 17: 240 -244.

[21] Bond, T.B. and Templeton, M.R. 2011. History and future of domestic biogas plants in the developing world, Energy for Sustainable Development, 15:347-354.

[22] Shane, A., Gheewala, S.H. and Phiri, S. 2017. Rural domestic biogas supply model for Zambia, Renewable and Sustainable Energy Reviews, 78:, 683-697.

[23] Thailand Greenhouse Gas Management Organization, 2015. Greenhouse gas emissions from fertiliser. www.haicarbonlabel.tgo.or.th/tools/files.php? (Accessed March 27, 2017).

[24] Kool, A., Marinussen, M., Blonk, H. LCI data for the calculation tool Feedprint for greenhouse gas emissions of feed production and utilization, GHG Emissions of N, P and K fertiliser production, 2012.

[25] Intergovernmental Panel on Climate Change, 2006. Guidelines for National Greenhouse Gas Inventories, National Greenhouse Gas Inventories Programme, Volume 4, Agriculture, forestry and other land uses, Chapter 11: Generic methodologies applicable to multiple land use category, Tokyo: Institute for Global Environmental Strategies.

[26] Elsgaard, L. 2010. Greenhouse Gas Emissions from cultivation of winter wheat and winter rapeseed for biofuels and from production of biogas from manure, Aarhus University.

[27] Figueiredo, E.B., Panosso, A.R., Romao, R. and La Scala Jr, N.R. 2010. Greenhouse gas emission associated with sugar production in southern Brazil. Carbon Balance and Management, 5(3): 1-7.

[28] Intergovernmental Panel on Climate Change, 2006. Guidelines for National Greenhouse Gas Inventories, National Greenhouse Gas Inventories Programme Volume 2, Energy, Chapter 2: Stationary combustion, Tokyo: Institute for Global Environmental Strategies.

[29] Chakrabarty, S. MuktadirBoksh, F.I.M. and Chakraborty, A. 2013. Economic viability of biogas and green self-employment opportunities, Renewable and Sustainable Energy Reviews, 28: 757-766.

[30] Kang, J.Y., Kang, D.W., Kim, T.S. and Hur, K.B. 2014. Comparative economic analysis of gas turbine based power generation and combined heat and power systems using biogas fuel. Energy, 67: 309-318.

[31] United Nations Environmental Programme, 2015. Strategies and mechanisms for promoting cleaner production investments in developing countries: profiting from cleaner production performing net present value (NPV) Calculations.

[32] Shane, A., Gheewala, S.H., Fungtammasan, B., Bonnet, S., Silaletruksa, T. and Phiri, S. 2016. Bioenergy resource assessment for Zambia, Renewable and Sustainable Energy Reviews, 53: 93-104.

[33] Environmental Council of Zambia, 2008. Zambia Environmental Outlook Report 3: Lusaka: Environmental Council of Zambia. 
[34] Thapa, S. and Keyser, J. 2012. Agriculture and environmental services, Agribusiness indicators: Zambia. World Bank, Washington DC.

[35] Dilidili, J.Q., Polinga, C.A., Ararao-Pelle, R. and Sangalang, R.S. 2011. Biogas technology in Philippines: A synthesis of various readings on biogas technology, Cavite.

[36] International Fertiliser Industry Association Fertilisers, 2009. Climate Change and Enhancing Agricultural Productivity Sustainably, IFA, Paris, France.

[37] Al Seadi, T., Rutz, D., Prassl, H., Kottner, M., Finsterwalder, T., Volk, S. and Janssen, R. 2008. Biogas handbook, University of Southern Denmark.

[38] National Renewable Energy Laboratory, 2013. Feasibility study of anaerobic digestion of food waste in St. Bernard, Louisiana, The U.S. Environmental Protection Agency (EPA), National Renewable Energy Laboratory, Interagency Agreement IAG-08-0719 and Task No WFD3.1001.

[39] Shane, A, and Gheewala, SH. 2017. Missed environmental benefits of biogas production in Zambia, Cleaner Production, 142: 1200-1209.

[40] Demirel, Y. 2012. Energy, green energy and technology, 2012. DOI: 10.1007/978-1-4471-23729_2, Springer-Verlag, London.

[41] Senkwe, B.K. and Mwale, A.H. 2001. Solid waste in Kitwe: Solid waste characterization study for the city of Kitwe, Zambia, Phase 1, SINPA 28, Institute for housing and urban development studies, Rotterdam, Netherlands.

[42] Shane, A. and Gheewala, S.H. 2015. Missed environmental benefits of biogas production in Zambia, The $5^{\text {th }}$ international conference on green and sustainable innovation and the $5^{\text {th }}$ TIChE international conference, Dusit, Pattaya, Thailand, November 810.

[43] Smith J.U. 2013. The potential of small scale biogas digesters to improve livelihoods and long Term sustainability of ecosystem services in Sub-Saharan Africa, Department for International Development, UK.

[44] Hochloff, P. and Braun, M. 2014. Optimizing biogas plants with excess power unit and storage capacity in electricity and control reserve markets, $\mathrm{Bi}$ omass and Bioenergy, 65: 125-135.

[45] Akbulut, A. 2012. Techno-economic analysis of electricity and heat generation from farm-scale biogas plant: Çiçekdagi case study, Energy, 44: 381390.

[46] Riva, C., Schievano, A., D'Imporzano, G. and Adani, F. 2014. Production costs and operative margins in electric energy generation from biogas. Full-scale case studies in Italy. Waste Management, 34: 429-1435.

[47] Fischer, E., Schmidt, T., Hora, S., Giersdorf, J., Stinner, W. and Scholwin, F. 2010. Renewable Energy Project Development Programme East Africa. Agro-industrial biogas in Kenya: Potentials, estimates for tariffs, policy and business recommendations, German Agency for Technical Cooperation.
[48] Germany Energy Agency, 2010. The role of natural gas and biomethane in the fuel mix of the future in Germany: Required action and potential solutions to accelerate adoption in transport applications, etc.

[49] Zambia Environmental Management Agency, 2008. Environmental Management Act, Statutory Instrument, 12: 87-178.

[50] BOZ, 2010. Survey on how commercial banks determine lending interest rates in Zambia, Bank of Zambia.

[51] Mbao, F.Z., Kapembwa, C., Mooka, O., Rasmussen, T. and Sichalwe, J. 2014. Determinants of bank lending rates in Zambia: A balance sheet approach, Bank of Zambia Working Paper WP/02.

[52] Hahn, H., Ganagin, W., Hartmann, K. and Wachendorf, M. 2014. Cost analysis of concepts for a demand oriented biogas supply for flexible power generation, Bioresource Technology, 170: 211-220.

[53] Zambia Environmental Management Agency, Environmental impact assessment regulations, Statutory Instrument, 28: 93-117.

[54] Government Republic of Zambia, 2015. The Laws of Zambia, The Fees and Fines Act, Statutory Instrument No. 41 of 2015.

[55] Japanese International Corporation Agency, 2011. Cost of doing business in Zambia. JICA, 1-16.

[56] Zambia Revenue Authority, 2015. The tax system in Zambia, Lusaka.

[57] Allegue, L.B. and Hinge, J. 2012. Biogas and biosyngas upgrading report, Danish Technological Institute, Aarhus, Denmark.

[58] Petersson, A., and Wellinger, A. 2009. Biogas upgrading technologies - developments and innovations, IEA Bioenergy, Task 37 - Energy from biogas and landfill gas

[59] Hagen, M., Polman, E., Myken, A., Jensen, J., Jonsson, O. and Dahl, A. Adding gas from biomass to the gas grid. Final report Contract No: XVII/4.1030/Z/99 -412, 2001. 